\title{
Thyroid hormone and vitamin D regulate VGF expression and promoter activity
}

\author{
Jo E Lewis ${ }^{1,2}$, John M Brameld', Phil Hill', Dana Wilson³, Perry Barrett, \\ Francis J P Ebling ${ }^{2}$ and Preeti H Jethwa ${ }^{1}$ \\ ${ }^{1}$ Division of Nutritional Sciences, School of Biosciences, University of Nottingham, Sutton Bonington Campus, \\ Loughborough, LE12 5RD, UK \\ ${ }^{2}$ School of Life Sciences, University of Nottingham, Queen's Medical Centre, Nottingham NG7 2UH, UK \\ ${ }^{3}$ The Rowett Institute of Nutrition and Health, University of Aberdeen, Bucksburn, Aberdeen AB21 9SB, UK
}

Correspondence should be addressed to $\mathrm{P} \mathrm{H}$ Jethwa

Email

preeti.jethwa@ nottingham.ac.uk

\begin{abstract}
The Siberian hamster (Phodopus sungorus) survives winter by decreasing food intake and catabolizing abdominal fat reserves, resulting in a sustained, profound loss of body weight. Hypothalamic tanycytes are pivotal for this process. In these cells, short-winter photoperiods upregulate deiodinase 3 , an enzyme that regulates thyroid hormone availability, and downregulate genes encoding components of retinoic acid (RA) uptake and signaling. The aim of the current studies was to identify mechanisms by which seasonal changes in thyroid hormone and RA signaling from tanycytes might ultimately regulate appetite and energy expenditure. proVGF is one of the most abundant peptides in the mammalian brain, and studies have suggested a role for VGF-derived peptides in the photoperiodic regulation of body weight in the Siberian hamster. In silico studies identified possible thyroid and vitamin D response elements in the VGF promoter. Using the human neuroblastoma SH-SY5Y cell line, we demonstrate that RA increases endogenous VGF expression $(P<0.05)$ and VGF promoter activity $(P<0.0001)$. Similarly, treatment with 1,25 -dihydroxyvitamin $D_{3}$ increased endogenous VGF mRNA expression $(P<0.05)$ and VGF promoter activity $(P<0.0001)$, whereas triiodothyronine $\left(\mathrm{T}_{3}\right)$ decreased both $(P<0.01$ and $P<0.0001)$. Finally, intrahypothalamic administration of $\mathrm{T}_{3}$ blocked the short day-induced increase in VGF expression in the dorsomedial posterior arcuate nucleus of Siberian hamsters. Thus, we conclude that VGF expression is a likely target of photoperiod-induced changes in tanycyte-derived signals and is potentially a regulator of seasonal changes in appetite and energy expenditure.
\end{abstract}

\section{Keywords \\ - VGF (non-acronymic) \\ - thyroid hormone \\ - SH-SY5Y cells \\ - Siberian hamster \\ - vitamin D}

Journal of Molecular Endocrinology (2016) 56, 123-134

\section{Introduction}

The Siberian hamster (Phodopus sungorus) has been increasingly used to investigate hypothalamic mechanisms regulating energy homeostasis due to its natural seasonal cycle of appetite, energy expenditure, and body weight (Ebling 2014). These hamsters naturally become obese in the summer long-day photoperiod (LD), but then enter a catabolic state during winter short-day photoperiod
(SD) where they reduce their food intake and catabolize intra-abdominal fat reserves, subsequently losing up to a third of their body weight (Bartness et al. 1989, Klingenspor et al. 1996, Mercer et al. 2001). The mechanism(s) by which these long-term changes in body weight are regulated are poorly understood, but they are clearly distinct from those governing short-term homeostatic regulation of 
appetite (Ebling 2015). The expression of a number of genes has been shown to be altered in the ventral ependymal wall lining the hypothalamic third ventricle of Siberian hamsters housed in different photoperiods (Barrett et al. 2005, 2006). Much recent interest has focused on tanycytes as the key component of the ependyma, as these cells are clearly important nutrient sensors in the hypothalamus, and also a stem cell niche (Bolborea \& Dale 2013, Robins et al. 2013). For example, SD photoperiod upregulates expression of deiodinase 3 (DIO3), the enzyme responsible for degrading active 3,5,3'-triiodothyronine $\left(\mathrm{T}_{3}\right)$ to inactive $3,3^{\prime}$-diiodothyronine $\left(\mathrm{T}_{2}\right)$, as well as the conversion of thyroxine $\left(\mathrm{T}_{4}\right)$ to the inactive 3,3',5-triodothyronine, also called reverse $\mathrm{T}_{3}$ or $\mathrm{rT}_{3}$ (Barrett et al. 2005, 2006, 2007). A number of genes encoding components of retinoic acid (RA) uptake and signaling are also downregulated by SD in tanycytes (Ross et al. 2004, Shearer et al. 2010). The major question now arises as to how seasonal changes in thyroid hormone and RA signaling from tanycytes to hypothalamic neurons ultimately regulate appetite and energy expenditure.

One of the most abundant peptidergic genes expressed in the mammalian brain, and particularly the hypothalamus, is VGF (non-acronymic) (Levi et al. 2004, Lewis et al. 2015b), a gene first identified on the basis of its rapid induction in vitro by nerve growth factor (NGF) in PC12 cells, a rat neuroblastic cell line (Levi et al. 1985). It has subsequently been shown that RA, in addition to $\mathrm{NGF}$, can act as a transcriptional inducer of the $V G F$ gene in SK-N-BE (a human neuroblastoma cell line) and PC12 cells (Salton et al. 1991, Rossi et al. 1992, Cerchia et al. 2006). Hypothalamic VGF mRNA expression is altered by photoperiod in Siberian hamsters, with significantly lower expression in SD compared to LD in the arcuate nucleus (ARC), but intriguingly upregulation in a specific subdivision of the ARC, the dorsomedial posterior ARC (dmpARC), defined by expression of histamine 3 receptors (Barrett et al. 2005). After switching to LD, VGF expression in the dmpARC decreased rapidly, ahead of body weight changes (Barrett et al. 2005). We have previously shown that intracerebroventricular administration of the VGFderived peptide, TLQP-21, decreased appetite and body weight in Siberian hamsters in LD (Jethwa et al. 2007), supporting the view that the products of this gene might impact upon seasonal behavior and physiology. In silico analysis of the mouse VGF promoter sequence revealed a potential thyroid response element (TRE), as well as a vitamin $\mathrm{D}$ response element (VDRE). We previously demonstrated that thyroid hormone $\left(\mathrm{T}_{3}\right)$ availability in the hypothalamus was likely to be reduced in hamsters in SD, due to increase in DIO3 expression (Barrett et al. 2007, Murphy et al. 2012), while changes in vitamin D production have also previously been associated with photoperiod, particularly in the human kidney and skin (Webb et al. 1988, Holick 1995). Understanding the interactions of these regulatory factors is necessary to establish the mechanisms which promote the catabolic state observed in Siberian hamsters in SD. Thus, we investigated the effects of thyroid hormone $\left(\mathrm{T}_{3}\right), \mathrm{RA}$ and vitamin $\mathrm{D}\left(1,25\right.$-dihydroxyvitamin $\left.\mathrm{D}_{3}\left[1,25 \mathrm{D}_{3}\right]\right)$ on VGF mRNA expression and promoter activity in vitro. The experimental approach was to use the SH-SY5Y neuroblastoma cell line, a common neuronal cell model due to its ability to differentiate into a more mature neuron-like phenotype and to be propagated unlike primary mammalian neurons (Dwane et al. 2013, Kovalevich \& Langford 2013). These in vitro studies were complemented by an investigation of the effects of intra-hypothalamic implantation of $\mathrm{T}_{3}$ on the expression of VGF in the hypothalamus of Siberian hamsters, a procedure previously demonstrated to maintain an anabolic phenotype characteristic of LD exposure (Barrett et al. 2007, Murphy et al. 2012).

\section{Methods}

\section{Materials}

Unless stated otherwise, all chemicals for cell culture were purchased from Sigma-Aldrich, while those for RNA extraction, complimentary DNA (cDNA) synthesis and quantitative PCR (QPCR) were purchased from Roche Life Science. $\mathrm{RA}, \mathrm{T}_{3}$, and $1,25 \mathrm{D}_{3}$ were obtained from Sigma-Aldrich and NGF was supplied by Millipore (Telecula, CA, USA) and was diluted as per manufacturer's instructions. RA was reconstituted in 95\% ethanol at $2.7 \mathrm{mg} / \mathrm{ml}$; subsequent dilutions were made in DMEM with a final ethanol concentration of $0.1 \%(\mathrm{v} / \mathrm{v})$. NGF (10 $\mu \mathrm{g} / \mathrm{ml})$ was reconstituted in sterile DMEM; subsequent dilutions were made in sterile DMEM. $\mathrm{T}_{3}$ was reconstituted in $1.0 \mathrm{ml} 1.0 \mathrm{M} \mathrm{NaOH}(20 \mu \mathrm{g} / \mathrm{ml})$ and $49 \mathrm{ml}$ sterile DMEM; subsequent dilutions were made in DMEM. $1,25 \mathrm{D}_{3}$ was reconstituted in 95\% ethanol $(10 \mu \mathrm{M})$; subsequent dilutions were made in sterile DMEM.

\section{Cell culture}

The human neuroblastoma SH-SY5Y cells (a kind gift from Dr Perry Barrett, but originally from European Collection of Cell Cultures (ECACC) Centre for Applied Microbiology and Research (CAMR), Porton Down Salisbury,

Published by Bioscientifica Ltd. 
Wiltshire, UK) were grown in uncoated $25 \mathrm{~cm}^{2}$ tissue culture flasks in DMEM/Ham's F-12 containing 10\% fetal bovine serum (FBS), 100 units/l penicillin and $100 \mathrm{mg} / \mathrm{l}$ streptomycin (DMEM/F12 complete) maintained at $37{ }^{\circ} \mathrm{C}$ in a 95\% humidified incubator with $5 \% \mathrm{CO}_{2}$ (Lewis et al. 2015a). Although SH-SY5Y cells tend not to adhere very well to uncoated plastic, they were routinely split $1: 3$ with $0.05 \%$ trypsin every $48 \mathrm{~h}$.

\section{RNA extraction and cDNA synthesis}

Prior to harvesting the cells, the DMEM/F12 complete media was removed and cells were harvested in $200 \mu \mathrm{l}$ of RNase-free PBS. Total RNA was extracted from the cells using the High Pure Isolation Kit (Roche) as described previously (Brown et al. 2012). First-strand cDNA was synthesized using the Transcriptor First Strand cDNA Synthesis Kit (Roche), according to the manufacturer's protocol. The cDNA was stored at $-20{ }^{\circ} \mathrm{C}$.

\section{Quantitative RT-PCR}

The PCR was performed with SYBR green optimized for the LightCycler 480 (Roche Life Science). All reactions were performed in triplicate on 384 well plates as described previously (Brown et al. 2012). Transcript abundance was determined from a standard curve produced using a serial dilution of pooled cDNA made from all samples to check linearity and efficiency of the PCR and the values normalized to cyclophilin $\mathrm{A}$, the most stable reference gene under the experimental conditions. The respective primer sets can be seen in Table 1 .

\section{Synthesis of the VGF promoter and other constructs}

First, the ZsGreen gene present in the promoterless pZsGreen1-1 vector (Clontech Laboratory) was replaced with CBG992AmRFP from pCR2CBG992AmRFP (pRFP, Stritzker et al. 2014). The subcloning strategy utilized BamHI and NotI; then both fragments were purified using the QIAquick gel extraction kit (QIAGEN), as per manufacturer's instructions. The pZsGreen1-1 backbone was treated with calf intestinal alkaline phosphatase (Promega) to prevent re-ligation of the plasmid without insert. This new reporter construct was designated pRFP-basic and was transformed into JM109 cells (Promega). Cultures were grown overnight, before plating and colony selection. All purified plasmids were subjected to restriction enzyme digestion and sequencing (performed by Source BioScience, Nottingham, UK) to confirm identity. Subsequently a cytomegalovirus (CMV) promoter, from pLenti6. 4-CMV-C/EBPPA (a kind gift from Prof Michael Lomax, University of Nottingham, UK), was cloned into the pRFPbasic vector. Using a similar strategy, pRFP-basic was digested with XhoI and SpeI, whilst pLenti6.4-CMV-C/ EBPPA was digested with SalI (which produces identical overhangs to XhoI) and SpeI (NEB, Hitchin, Hertfordshire, UK) to obtain the CMV promoter, which was subsequently ligated into the pRFP construct. This new construct was designated pCMV-RFP.

Approximately $1.1 \mathrm{~kb}$ of the mouse $V G F$ promoter $(-1151 \mathrm{bp}$ to $+51 \mathrm{bp}$, relative to the transcriptional start site; accession number: NM_001039385.1) was generated by PCR (see Table 1 for primers). The resultant amplicon was purified using the QIAquick gel extraction kit (QIAGEN), as per manufacturer's instructions, and inserted into the pGEM-T-Easy vector for subsequent subcloning into pRFP-basic using SpeI and SacI. Alternatively, MboI and $B g l$ II were used to create the truncated $0.5 \mathrm{~kb}$ promoter construct lacking the potential TRE and VDRE. The orientation and authenticity of these constructs, designated pVGF1.1 and pVGF0.5, were verified by sequencing (performed by Source BioScience, UK).

\section{Study 1: the long-term maintenance of differentiation of SH-SY5Y cells}

The SH-SY5Y cells demonstrate reduced neurite length, a marker of differentiation, when cultured on uncoated surfaces (Dwane et al. 2013). Therefore to establish culture conditions for the long-term maintenance of differentiated neuronal cells, SH-SY5Y cells were plated in

Table 1 The PCR primers used for QPCR analysis of gene expression or to amplify $1.1 \mathrm{~kb}$ of the VGF promoter.

\begin{tabular}{l} 
Gene \\
\hline Cyclophilin A \\
Map2 \\
Tau \\
Gap43 \\
VGF \\
VGF promoter
\end{tabular}

\begin{tabular}{l} 
Forward primer $\left(\mathbf{5}^{\prime} \mathbf{- \mathbf { 3 } ^ { \prime }}\right)$ \\
\hline TCCTGCTTTCAAGAATTATTCC \\
CATGGGTCACAGGGCACCTATTC \\
GCGGCAGTGTGCATATAGTCTACA \\
AGTGAGCAGCGAGCAGAA \\
GACCCTCCTCTCCACCTCTC \\
AAGGGTGTGGGAGAGTTGG
\end{tabular}

Forward primer $\left(5^{\prime}-3^{\prime}\right)$

CATGGT GCGGCAGTGTGCATATAGTCTACA GACCCTCCTCTCCACCTCTC AAGGGTGTGGGAGAGTTGG
Reverse primer $\left(5^{\prime}-3^{\prime}\right)$

ATTCGAGTTGTCACAGTCAGC GGTGGAGAAGGAGGCAGATTAGCTG GGAAGGTCAGCTTGTGGGTTTCAA GTTGCGGCCTATGAGCTT ACCGGCTCTTTATGCTCAGA GAGGGATGGACAGCGGAG http://jme.endocrinology-journals.org DOI: 10.1530/JME-15-0224
(C) 2016 The authors Printed in Great Britain
Published by Bioscientifica Ltd. 
six-well plates coated with or without $0.01 \%$ poly-L-lysine or $10 \mu \mathrm{g} / \mathrm{ml}$ collagen type IV. Cells were plated at $5 \times 10^{4}$ cells $/ \mathrm{cm}^{2}$ in DMEM/F12 complete, and $24 \mathrm{~h}$ later treated with $10 \mu \mathrm{M}$ RA in DMEM/F12 complete for $120 \mathrm{~h}$. Differentiation was subsequently maintained by treating the cells with $50 \mathrm{ng} / \mathrm{ml}$ NGF (Promega) in DMEM/F12 complete every $48 \mathrm{~h}$. Images were captured 24, 48, 72, 96 and $120 \mathrm{~h}$ post-differentiation and neurite length determined using ImagePro Software (version 4.0; Image Pro, Rockville, MD, USA). A differentiated cell was defined as a cell with a neurite length greater than the length of the cell body. At the end of the study, cells were harvested for RNA and subsequent QPCR to determine the expression of the known markers of neurite differentiation, microtubule-associated protein 2 (Map2), Tau and growth-associated protein 43 (GAP43) (Table 1).

\section{Study 2: regulation of endogenous expression of VGF mRNA in vitro}

To investigate the regulation of endogenous $V G F$ gene expression, undifferentiated SH-SY5Y cells were plated onto uncoated six-well plates for $24 \mathrm{~h}$. Subsequently, DMEM/F12 complete was removed and the cells treated with DMEM/F12 complete containing $50 \mathrm{ng} / \mathrm{ml} \mathrm{NGF}$,

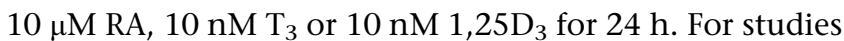
in differentiated SH-SY5Y cells, plates were coated with $10 \mu \mathrm{g} / \mathrm{ml}$ collagen type IV and differentiated as per study 1 . The adherent, differentiated cells were then treated with DMEM/F12 complete containing $50 \mathrm{ng} / \mathrm{ml} \mathrm{NGF,} 10 \mu \mathrm{M}$ RA, $10 \mathrm{nM} \mathrm{T}_{3}$ or $10 \mathrm{nM} 1,25 \mathrm{D}_{3}$ for $24 \mathrm{~h}$. Cells were harvested for RNA extraction and QPCR to determine endogenous expression of VGF.

\section{Study 3: regulation of VGF promoter activity in vitro}

To investigate the regulation of the $V G F$ promoter in undifferentiated cells, SH-SY5Y cells were plated onto uncoated six-well plates and grown to $70 \%$ confluence, prior to transfection in DMEM/F12 basic medium (DMEM/F12 containing 2.5\% FBS, without antibiotics). The undifferentiated cells were transfected with the various plasmids using the FuGENE HD (reagent: DNA ratio of 3:1) as per manufacturer's instructions. Briefly, undifferentiated cells were co-transfected with the VGF promoter construct (pVGF1.1 or pVGF0.5) and tenfold less pZsGreen1-N1 (Clontech Laboratories), a plasmid containing a variant of green fluorescent protein (GFP) under the control of a CMV promoter, with the latter used to correct for differences in transfection efficiency.
pCMV-RFP (i.e. a strong promoter) was used as a positive control, while pRFP-basic (a promoterless plasmid) was used as a negative control, with both again being co-transfected with pZsGreen1-N1 to normalize for variability in transfection efficiencies. Seventy-two hours posttransfection, undifferentiated cells were switched back to DMEM/F12 complete (with antibiotics) containing

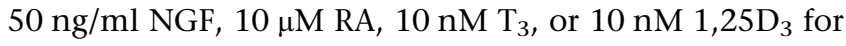
$48 \mathrm{~h}$. Promoter activities (fluorescence) were quantified at different time points using the Typhoon Trio+ (GE Healthcare, Little Chalfont, Buckinghamshire, UK).

In the experiments using differentiated cells, SH-SY5Y cells were grown to $70 \%$ confluence on uncoated six-well plates and transfected as before. The cells were then harvested using $0.05 \%$ trypsin, plated onto six-well plates coated with $10 \mu \mathrm{g} / \mathrm{ml}$ type IV collagen for $24 \mathrm{~h}$, before differentiation was induced with $10 \mu \mathrm{M}$ RA for $120 \mathrm{~h}$ (as before). Transfecting cells prior to differentiation have been shown to result in higher transfection efficiencies without altering the course of transgene expression (Lahousse et al. 2006, Chu et al. 2009). Transfected,

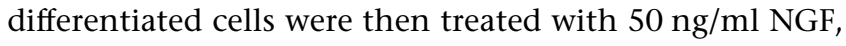
$10 \mu \mathrm{M} \mathrm{RA}, 10 \mathrm{nM} \mathrm{T}$, or $10 \mathrm{nM} 1,25 \mathrm{D}_{3}$ for $48 \mathrm{~h}$ to investigate effects on the VGF promoter activities (up to $120 \mathrm{~h}$ post-transfection). Promoter activities (fluorescence) were quantified at different time points using the Typhoon Trio + (GE Healthcare).

\section{Study 4: the effects of intra-hypothalamic $\mathrm{T}_{3}$ administration on VGF mRNA expression in Siberian hamsters exposed to LD or SD}

Hypothalamic expression of VGF was studied in tissues collected in a study previously described by Barrett et al. (2007). The study was carried out in age-matched adult male Siberian hamsters obtained from a colony bred in house (Ebling 1994), individually housed at constant temperature $\left(21 \pm 1{ }^{\circ} \mathrm{C}\right)$ and $40-50 \%$ humidity. Animals had access ad libitum to food (Teklad 2019, Harland, UK) and water throughout the studies. All animal procedures were approved by the University of Nottingham Local Ethical Review Committee and were carried out in accordance with the UK Animals (Scientific Procedures) Act of 1986 (Project License PPL 40/2372).

Anesthetized Siberian hamsters (aged 3-4 months) maintained in LD had either $\mathrm{T}_{3}$ (mixture of crystalline $\mathrm{T}_{3}$ and medical grade silicone/Silastic-brand adhesive) or sham (medical grade silicone/Silastic-brand adhesive alone) microimplants placed bilaterally into the hypothalamus $(6.5 \mathrm{~mm}$ below the surface of the dura at $0.5 \mathrm{~mm}$

Published by Bioscientifica Ltd. 
to the left of the midline as defined by the center of the superior midsagittal sinus) as previously described (Barrett et al. 2007). At 12-16 days post-surgery, the Siberian hamsters were subdivided according to bodyweight to be either maintained in LD ( $n=6 /$ group) or transferred into $\mathrm{SD}$ ( $n=7-8 /$ group). Animals were euthanized with sodium pentobarbital (Euthatal: Rhone Merieux, Harlow) at 8 weeks post-surgery, and in situ hybridization studies for VGF were carried out as previously described in Barrett et al. (2005).

To determine expression slides were scored for the density of silver grains over individual cells in the dmpARC reflecting hybridization of the VGF probe by an observer who was blind to the treatment: $0=$ no hybridization, $1=\mathrm{a}$ few cells expressing VGF mRNA, $2=$ moderate VGF mRNA expression cells, $3=$ abundant VGF mRNA. Scores were not possible for three animals as sections containing the dmpARC region were not available.

\section{Statistical analysis}

Data represent the means \pm s.E.M. of six technical replicates (i.e. wells). Significant differences between groups for dependent variables were tested using either an unpaired, two-tailed Student's t-test, one-way ANOVA in studies 1 and 2 or a two-way ANOVA (treatmentxtime) in study 3. In study 4 , scores were analyzed by a Kruskal-Wallis test with post hoc Dunn's tests for multiple comparisons. Changes in body weight (data represent the means \pm S.E.M.) and in paired testis weights over the course of the $\mathrm{T}_{3}$ treatment were compared using one-way ANOVA with post hoc Dunnett's tests for multiple comparisons. Statistical analyses were conducted using GraphPad PRISM (version 6.0, San Diego, CA, USA). Significance was accepted at $P<0.05$.

\section{Results}

\section{Study 1: the long-term maintenance of differentiation of SH-SY5Y cells}

Treatment of the SH-SY5Y cells with $10 \mu \mathrm{M}$ RA for 5 days significantly reduced proliferation (Fig. 1A and B, $P<0.01)$. The cells underwent a significant change in morphology, with the length of neurites significantly increasing in response to $10 \mu \mathrm{M}$ RA (Fig. $1 \mathrm{~A}$ and C, $P<0.0001)$. By coating the cell culture wells with an extracellular matrix protein such as poly-L-lysine or
A

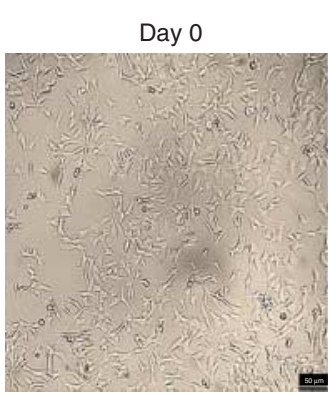

+5 days DMEM/F12 complete

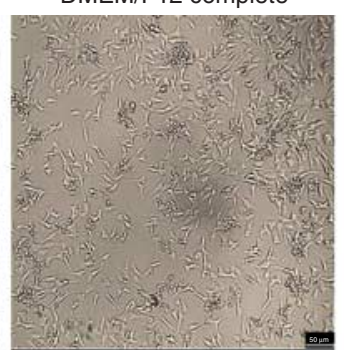

+5 days DMEM/F12complete + $10 \mu \mathrm{M}$ RA

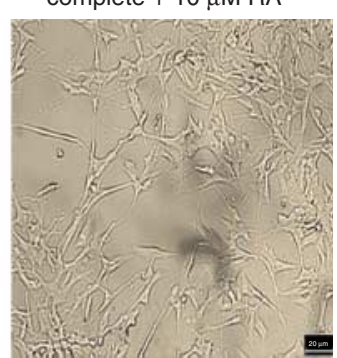

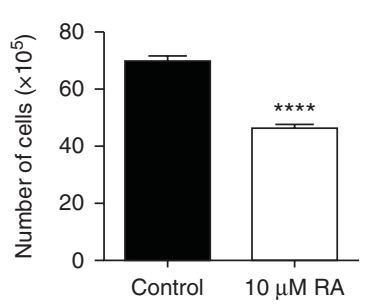

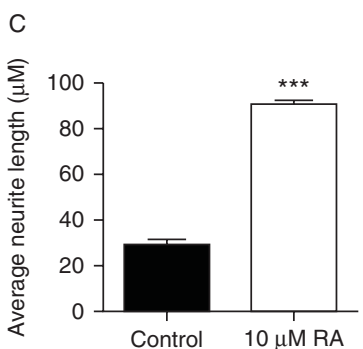

Control $10 \mu \mathrm{M}$ RA
D

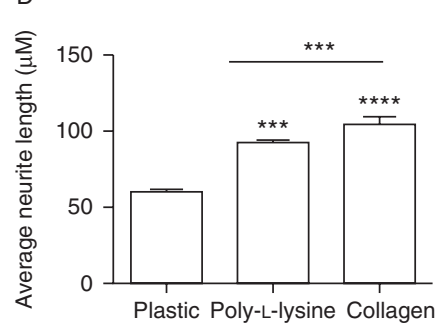

E

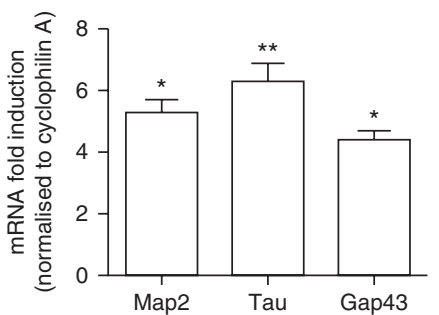

\section{Figure 1}

Treatment of the SH-SY5Y cell line with $10 \mu \mathrm{M}$ RA reduces cell proliferation and increases differentiation. (A) Images of SH-SY5Y cells at days 0 and 5 of differentiation in the absence or presence of $10 \mu \mathrm{M} R A$, showing differences in cell numbers and morphology (neurite lengths). (B) Treatment of the SH-SY5Y cell line with $10 \mu \mathrm{M}$ RA significantly decreased cell number $(P<0.0001)$ and $(C)$ significantly increased neurite length (a marker of differentiation) $(P<0.0001)$. (D) Neurite length was significantly greater http://jme.endocrinology-journals.org DOI: $10.1530 / J M E-15-0224$
(C) 2016 The authors Printed in Great Britain
5 days post-treatment with differentiation media in wells coated with polyL-lysine or type IV collagen $(P<0.0001)$ than plastic. $(E)$ Treatment of the SH-SY5Y cell line with differentiation media significantly increased Map2, Tau and Gap43 (neuronal markers of differentiation). Gene expression was quantified by QPCR, normalized to cyclophilin A mRNA, and then compared to the normalized expression in undifferentiated cells. All values are means \pm S.E.M. $(n=6, * P<0.05, * * P<0.01, * * * P<0.001$, and $* * * * P<0.0001)$.

Published by Bioscientifica Ltd. 
type IV collagen, neurite outgrowth was significantly enhanced (Fig. 1D, $P<0.0001$ ). Expression of Map2, Tau, and Gap43 mRNA were all significantly increased in comparison to undifferentiated controls (Fig. 1E, $P<0.05$ ). To ensure a homogenous population of differentiated SH-SY5Y cells, differentiated cells were then treated with $50 \mathrm{ng} / \mathrm{ml}$ NGF every $48 \mathrm{~h}$. Under these conditions, cultures of differentiated cells could be maintained for up to 20 days without reversion or cell death.

\section{Study 2: regulation of endogenous expression of VGF mRNA in vitro}

Treatment of undifferentiated SH-SY5Y cells with $50 \mathrm{ng} / \mathrm{ml} \mathrm{NGF}$ for 24 and $48 \mathrm{~h}$ significantly increased VGF mRNA five- and threefold (Fig. $2 \mathrm{~A}, P<0.01$ and $P<0.05$ vs vehicle treated controls), while treatment with $10 \mu \mathrm{M}$ RA significantly increased VGF mRNA two- and fourfold at 24 and $48 \mathrm{~h}$, respectively (Fig. $2 \mathrm{~A}, P<0.05$ vs vehicle treated controls). Similar effects of NGF and RA were observed in differentiated SH-SY5Y cells, but the magnitude of the responses to NGF were bigger (Fig. 2B). Further studies showed that treatment of undifferentiated SH-SY5Y cells with $10 \mathrm{nM} 1,25 \mathrm{D}_{3}$ for $24 \mathrm{~h}$ resulted in a threefold increase in VGF mRNA $(P<0.05)$, whereas treatment with $10 \mathrm{nM} \mathrm{T}_{3}$ resulted in a fourfold decrease $(P<0.01)$ in VGF mRNA (Fig. 2C), with similar effects again observed in differentiated SH-SY5Y cells, although the inhibitory effect of $\mathrm{T}_{3}$ tended to be greater (Fig. 2D).

\section{Study 3: regulation of VGF promoter activity in vitro}

Transfection of undifferentiated SH-SY5Y cells with pVGF0.5 or pVGF1.1 (containing 0.5 and $1.1 \mathrm{~kb}$ of the $5^{\prime}$ flanking region of the VGF promoter respectively
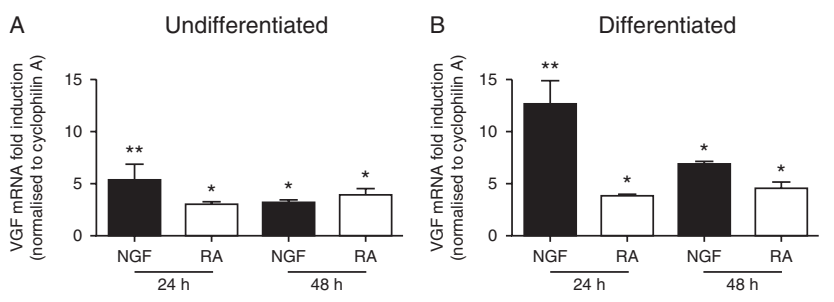

Figure 2

Treatment of undifferentiated or differentiated SH-SY5Y cells with NGF, RA or $1,25 D_{3}$ increases endogenous VGF mRNA expression, whereas $T_{3}$ decreases endogenous VGF mRNA. VGF mRNA was significantly increased by treatment with $50 \mathrm{ng} / \mathrm{ml} \mathrm{NGF}$ or $10 \mu \mathrm{M}$ RA for 24 and $48 \mathrm{~h}$ in both (A) undifferentiated SH-SY5Y cells and (B) differentiated SH-SY5Y cells.
(Fig. 3A)) resulted in significant increases in fluorescence, indicating promoter activity, but there was no difference between them $(P>0.05$, Fig. 3B). Treatment of transfected undifferentiated SH-SY5Y cells with either $10 \mu \mathrm{M}$ RA or $50 \mathrm{ng} / \mathrm{ml} \mathrm{NGF}$ resulted in significant increases in VGF promoter activities, with NGF inducing a much faster response than RA (time vs treatment interaction: $F=27.94, P<0.0001$, Fig. 3C). Similar time-dependent effects of both NGF and RA were observed in differentiated SH-SY5Y cells (time vs treatment interaction: $F=30.91$, $P<0.0001$, Fig. 3D). In both undifferentiated and differentiated SH-SY5Y cells, treatment with NGF resulted in a rapid induction of VGF promoter activity, whereas RA showed a much slower response with a delayed onset. Given the effect of $\mathrm{T}_{3}$ on endogenous VGF mRNA, transfected cells for promoter studies were pre-treated with $50 \mathrm{ng} / \mathrm{ml} \mathrm{NGF}$ for $1 \mathrm{~h}$ (to briefly induce promoter activity), before removal and treatment with $10 \mathrm{nM} \mathrm{T}_{3}$. Treatment of undifferentiated or differentiated SH-SY5Y cells with $10 \mathrm{nM} \mathrm{T}_{3}$ significantly decreased promoter activity for the pVGF1.1 construct (time vs treatment interaction: $F=86.13, P<0.0001$, Fig. 3E and F), while treatment with $10 \mathrm{nM} 1,25 \mathrm{D}_{3}$ resulted in a significant increase in pVGF1.1 promoter activity (time vs treatment interaction: $F=14.58, P<0.0001$, Fig. $3 \mathrm{G}$ and $\mathrm{H})$. There were no effects $(P>0.05)$ of either $10 \mathrm{nM} \mathrm{T}$ or $10 \mathrm{nM} 1,25 \mathrm{D}_{3}$ on activity of the truncated plasmid (pVGF0.5), confirming that the response elements for the two nuclear receptors were only present in the longer promoter construct.

\section{Study 4: the effects of intra-hypothalamic $T_{3}$ administration on VGF mRNA expression in Siberian hamsters exposed to LD or SD}

As previously reported (Barrett et al. 2007) exposure to SD for 8 weeks induced significant body weight loss $(P<0.01$,
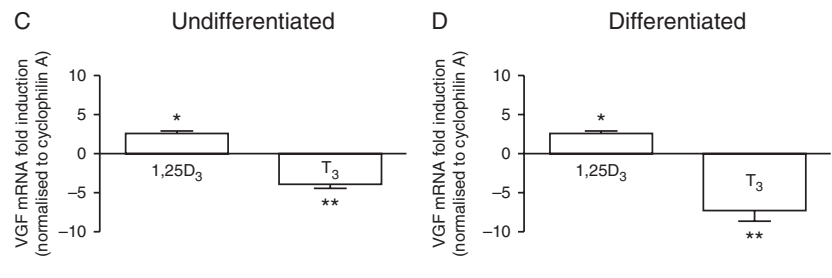

VGF mRNA was significantly increased by treatment with $10 \mathrm{nM} 1,25 \mathrm{D}_{3}$ but significantly reduced with $10 \mathrm{nM} \mathrm{T}_{3}$ in both (C) undifferentiated SH-SY5Y cells and (D) differentiated SH-SY5Y cells. All values are means \pm S.E.M. $(n=6, * P<0.05, * * P<0.01$ for comparisons between control and treatment).

Published by Bioscientifica Ltd. 
A
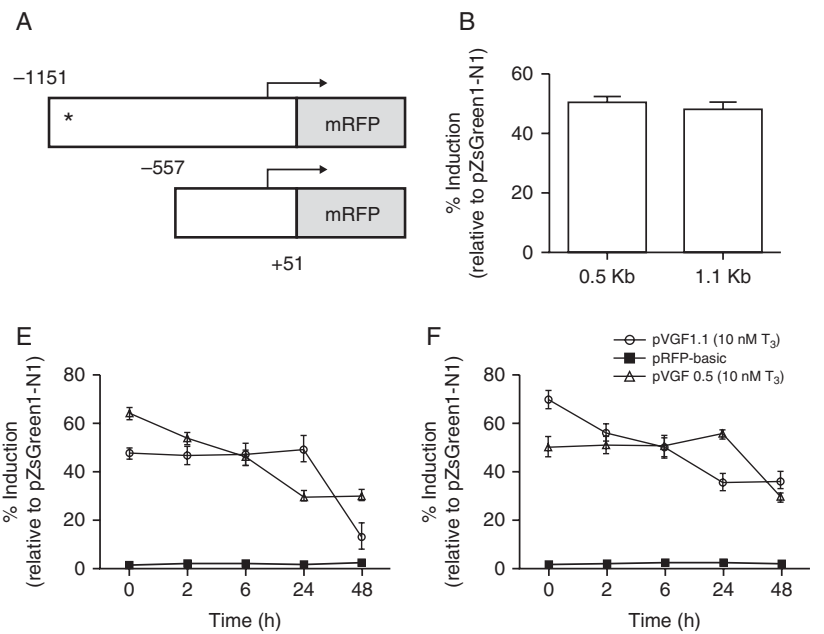

Figure 3

Treatment of undifferentiated or differentiated SH-SY5Y cells with NGF, RA or $1,25 D_{3}$ increases VGF promoter activity, whereas $T_{3}$ reduces VGF promoter activity. (A) The VGF promoter $(1.1 \mathrm{~kb})$ was cloned into a mammalian expression vector, based on the backbone of pZsGreen 1-1 (Clontech), in which the GFP reporter gene was substituted for an mRFP. A subsequent truncated promoter construct $(0.5 \mathrm{~kb})$, which lacked the potential TRE and VDRE (indicated as *), was generated via $5^{\prime}$ deletion. (B) Promoter activities (fluorescence) were similar in cells transfected with either the 1.1 or $0.5 \mathrm{~kb}$ VGF promoter constructs. Promoter activities are shown relative to the positive control (pZsGreen1-N1, fluorescence set at $100 \%$ ). VGF promoter activity (pVGF1.1 construct only) was increased by $50 \mathrm{ng} / \mathrm{ml} \mathrm{NGF}$ and $10 \mu \mathrm{M}$ RA in both (C) undifferentiated and (D) differentiated SH-SY5Y cells. (C) SH-SY5Y cells were transfected with pVGF1.1 and treated with NGF or RA $72 \mathrm{~h}$ post-transfection. $50 \mathrm{ng} / \mathrm{ml}$ NGF rapidly induced pVGF1.1 promoter activity within $1 \mathrm{~h}(P<0.0001)$. Ten micromolar RA resulted in a slower, yet significant, increase in pVGF1.1 promoter activity, starting 6 h post-treatment $(P<0.001)$. (D) Undifferentiated cells were transfected as described in (B), but $72 \mathrm{~h}$ post-transfection, cells were differentiated with $10 \mu \mathrm{M}$ RA for 5 days.

Fig. 4C) and testicular regression $(P<0.001$, Fig. 4D), and both these physiological responses to SD were completely blocked by intra-hypothalamic $\mathrm{T}_{3}$ implants (Fig. $4 \mathrm{C}$ and D). As expected, a very low level of VGF expression was observed in the dmpARC in hamsters which were maintained in LD and received either intrahypothalamic sham or $T_{3}$ implants, that is a very small number of cells in this region expressed VGF mRNA (Fig. 4A and B). In contrast, VGF mRNA expression was abundant in the dmpARC of sham-implanted hamsters exposed to SD for 8 weeks $(P<0.001$, Fig. $4 \mathrm{~A}$ and $\mathrm{B})$. Intra-hypothalamic implantation of $\mathrm{T}_{3}$ significantly blocked this SD-induced increase in VGF mRNA abundance $(P<0.05$, Fig. $4 A$ and $B)$. Intrahypothalamic implantation of $\mathrm{T}_{3}$ had no effect on VGF mRNA abundance or on any physiological parameters in hamsters that were maintained in LD (Fig. 4A, B, $\mathrm{C}$, and $\mathrm{D}$ ). In the one hamster where the SD-induced
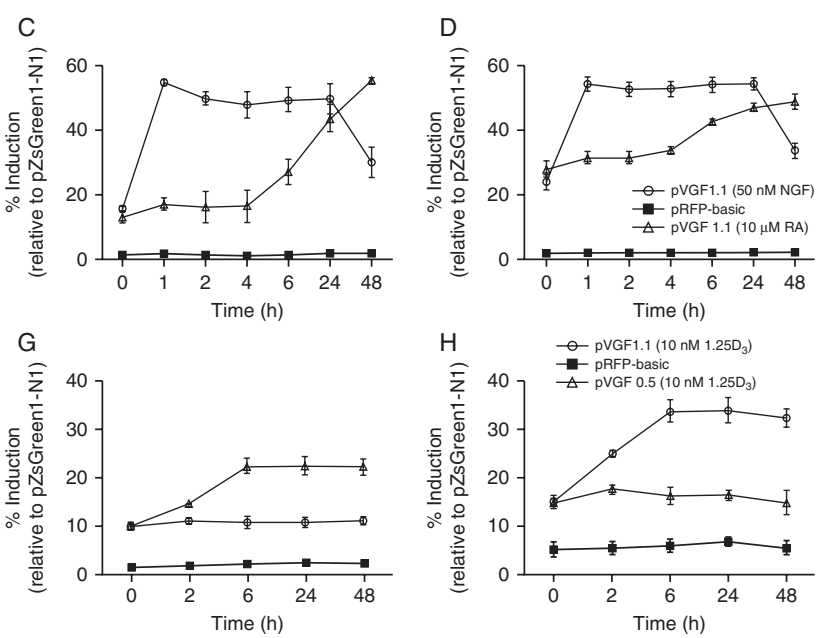

Differentiated transfected cells were then treated with $50 \mathrm{ng} / \mathrm{ml} \mathrm{NGF}$ or $10 \mu \mathrm{M}$ RA for $48 \mathrm{~h}$. Treatment of differentiated SH-SY5Y cells with NGF $(P<0.0001)$ and RA $(P<0.0001)$ had a similar effect to that observed in transfected undifferentiated cells. VGF promoter activity (pVGF1.1 construct only) was decreased by $10 \mathrm{nM} \mathrm{T}_{3}$ in both (E) undifferentiated and (F) differentiated SH-SY5Y cells, but there were no effects on the pVGF0.5 promoter construct (which lacked the potential TRE). Cells were transfected and differentiated as described for (B) and (D) respectively, but cells were pre-treated with DMEM/F12 complete containing $50 \mathrm{ng} / \mathrm{ml}$ NGF for $1 \mathrm{~h}$ (to induce promoter activity) prior to addition of $10 \mathrm{nM} \mathrm{T}_{3}$, which significantly reduced pVGF1.1 promoter activity $(P<0.001)$ in both $(\mathrm{E})$ undifferentiated and $(F)$ differentiated cells. Similarly, treatment with $10 \mathrm{nM} 1,25 \mathrm{D}_{3}$ significantly increased pVGF1.1 promoter activities $(P<0.0001)$ in both $(G)$ undifferentiated and $(H)$ differentiated cells, but there were no effects on the pVGF0.5 promoter construct (which lacked the potential VDRE). pRFP-basic was included as a negative control in all experiments to indicate background fluorescence, as this construct lacks a functional promoter. All values are means \pm s.E.M. $(n=6)$.

increase in VGF abundance was not prevented by the $\mathrm{T}_{3}$ treatment, the SD-induced involution of the testes was not blocked (Fig. 4D), and the hamster lost $3.3 \mathrm{~g}$ of body weight thus the SD-induced catabolic response was not prevented.

\section{Discussion}

Tissue-specific expression of the VGF gene has been previously described (Canu et al. 1997), but what other regulatory elements are present within the promoter remain to be established (Levi et al. 2004). Using the human neuroblastoma SH-SY5Y cell line, we have demonstrated that RA and NGF increase both endogenous $V G F$ mRNA expression and VGF promoter activity. The increase confirms the rise in VGF mRNA demonstrated in response to treatment with NGF in PC12 cells and to

Published by Bioscientifica Ltd 
A

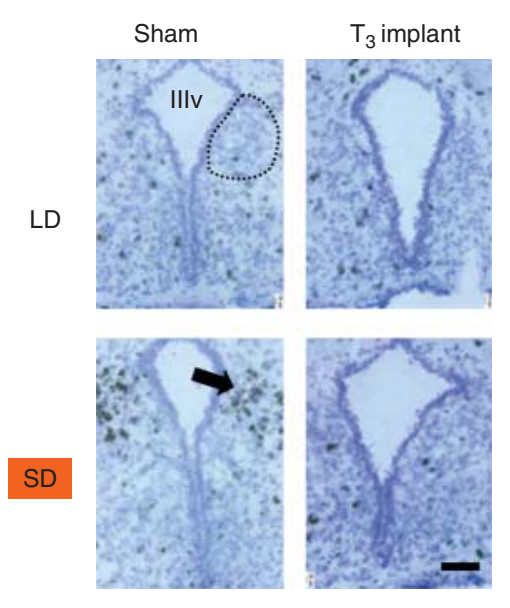

B

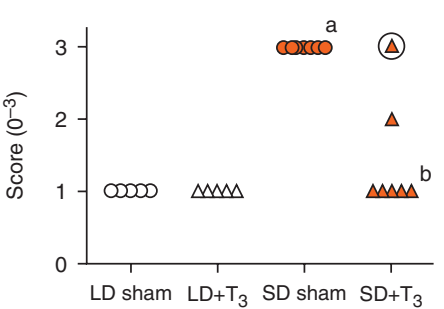

C

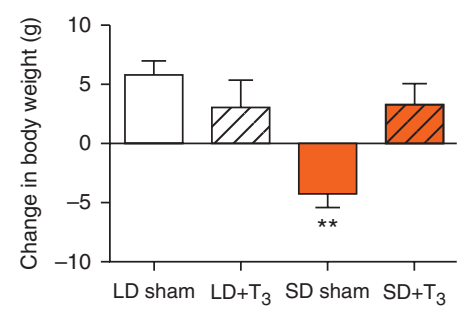

D

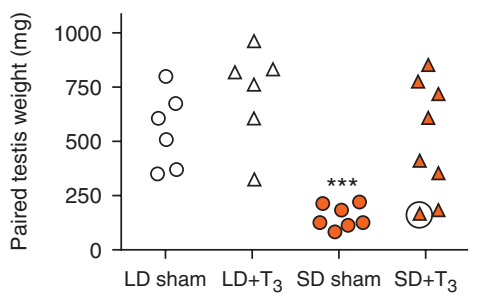

\section{Figure 4}

Intra-hypothalamic $T_{3}$ administration reduces VGF mRNA expression in the SD Siberian hamster. (A) representative photomicrographs of coronal sections through the dmpARC counterstained with cresyl violet, VGF hybridization is revealed by dark silver grains in the overlying emulsion in Siberian hamsters exposed to $L D$ or SD receiving intra-hypothalamic sham or $\mathrm{T}_{3}$ implants for 8 weeks. Dotted line indicates approximate boundaries of the dmpARC, arrow indicates induces expression in a SD sham hamster,

RA in SK-N-BE cells (Levi et al. 1985, Cerchia et al. 2006). Whilst the increase in VGF mRNA and promoter activity in response to treatment with NGF was rapid, it was rather transient, decreasing after $24 \mathrm{~h}$. In contrast, treatment with RA resulted in a much slower-, longer-term induction of VGF promoter activity, which continued to increase through to $48 \mathrm{~h}$.

In silico studies identified possible TRE and VDRE sequences in the VGF promoter, and our studies have shown that both endogenous VGF mRNA expression and VGF promoter activity are suppressed by $\mathrm{T}_{3}$ treatment, but increased with $1,25 \mathrm{D}_{3}$. Correspondingly, an in vivo study revealed that intra-hypothalamic $\mathrm{T}_{3}$ administration via slow-release microimplants reduced VGF mRNA expression in the dmpARC of SD-exposed Siberian hamsters. This suggests that VGF expression in vivo may be regulated by availability of these hormones/ligands, which in turn are determined by the transport of their precursors and the enzymes responsible for synthesizing or degrading their active forms. Substantial evidence indicates that the generation of thyroid hormone and RA signals in the mediobasal hypothalamus is regulated by season and photoperiod (discussed by Ebling (2014, 2015)). For example, expression of the genes encoding many of the components of the RA-signaling pathway (cellular retinol-binding protein-1 (CRBP-1), cellular scale bar $=100 \mu \mathrm{m}$. (B) analysis of $V G F m R N A$ abundance, scores for individual animals are depicted; ${ }^{\mathrm{a}} P<0.001$ vs LD sham group, ${ }^{\mathrm{b}} P<0.05$ vs SD sham group. (C) overall change in body weight, values are mean \pm s.E.M., $* * P<0.01$ vs LD-sham group. (D) individual paired testis weights at the end of the study, $* * * P<0.001$ vs LD-sham group. Weekly mean body weight data and group mean testis weight data have been published previously (Barrett et al. 2007). Circled values (panels (B) and (D)) are data from the same individual.

RA-binding protein-2 (CRABP-2) and the nuclear receptors, RAR and $\mathrm{RXR}$ ) is reduced in response to $\mathrm{SD}$ in the Siberian hamster (Ross et al. 2005, Barrett et al. 2006), so this may explain why VGF mRNA expression is reduced in the hypothalamus of Siberian hamsters exposed to SD (Barrett et al. 2005). Furthermore, in a photoperiodresponsive strain of rat, expression of RALDH-1, which converts retinol to $\mathrm{RA}$, is also reduced in the hypothalamus in SD (Shearer et al. 2010). Transthyretin (TTR) is a transporter for vitamin $\mathrm{A}$ and its metabolite RA as well as $\mathrm{T}_{4}$. TTR binds $\mathrm{T}_{4}$ to establish a pool of $\mathrm{T}_{4}$ in the plasma and cerebral spinal fluid (Prendergast et al. 2002) as well as transporting retinol by binding to the RBP (Hyung et al. 2010). However, studies utilizing TTR null mice have shown that while there are reductions in retinol and RBP in these mice, they display no symptoms of vitamin A deficiency, suggesting that TTR is not crucial for retinol delivery (Episkopou et al. 1993, van Bennekum et al. 2001). Thus, local availability of RA is determined by RALDH-1 and components of its signalling pathways (CRBP-1, CRABP-2 and RAR and RXR). All of which, as explained above, are reduced in response to $\mathrm{SD}$ in the Siberian hamster (Ross et al. 2005, Barrett et al. 2006, Shearer et al. 2010). Indeed, TTR expression in the hypothalamus of Siberian hamsters has been reported and the responsiveness of the gene was limited to the

Published by Bioscientifica Ltd. 
photorefractory state (Prendergast et al. 2002). TTR mRNA is strongly expressed in the ependymal layer of the third ventricle and is decreased in SD (relative to LD) (Helfer et al. 2012), thus resulting in reductions in local $\mathrm{T}_{4}$ availability. This in combination with the reduction in mRNA expression of DIO2 and increased expression and activity of DIO3 is observed in Siberian hamsters maintained in SD (Watanabe et al. 2004, Barrett et al. 2007, Herwig et al. 2009), and this results in a decrease in $T_{3}$. However, in the absence of RA, we suggest VGF expression would remain low in the hypothalamus of hamsters maintained in SD; thus we propose reduced RA in the hypothalamus of Siberian hamsters in response to SD results in reduced VGF expression (as demonstrated by Barrett et al. (2005)).

Previously, both vitamin A and RXR ligands have been shown to influence appetite (Anzano et al. 1979, Ogilvie et al. 2004). Therefore, the reduction in the availability of RA and components of its signaling pathway in the hypothalamus of Siberian hamsters in SD and subsequent reduction in VGF expression in the hypothalamus is a possible explanation for the effects on appetite. The complexity of the hormonal regulation of VGF expression that the current study has revealed may also explain why in SD there is a local upregulation of VGF expression in the dmpARC. In the hamster, this region has a much higher level of expression of thyroid hormone receptor b1 than the surrounding hypothalamus (Barrett et al. 2007), and our current study demonstrates that VGF mRNA expression in the dmpARC is specifically regulated by thyroid hormone. Thus, the SD-induced increase in DIO3 expression in tanycytes would be expected to reduce local $\mathrm{T}_{3}$ availability, resulting in a loss of repression of VGF gene expression in the dmpARC. Previously we demonstrated effects of increasing hypothalamic $T_{3}$ availability on the behavior and physiology of SD-exposed Siberian hamsters. Intra-hypothalamic $\mathrm{T}_{3}$ implants placed in hamsters in $\mathrm{SD}$ produced a rapid increase in body weight, a reflection of increased food intake and a decrease in energy expenditure (Murphy et al. 2012). Here, we demonstrate that locally increasing hypothalamic $\mathrm{T}_{3}$ blocks the SD-induced increase in $V G F$ mRNA expression in Siberian hamsters. This is associated with a blockade of the SD-induced decrease in appetite and in weight loss, and also with the SD-induced inactivation of the reproductive axis. The correlation between $V G F$ expression in the dmpARC and the physiological responses to SD was particularly highlighted in one individual hamster where the intrahypothalamic $T_{3}$ implants were ineffective in preventing any of the SD responses, probably because their placement was too rostral to influence hypothalamic function. The question now arises as to the specific role of $\mathrm{T}_{3}$-regulated $V G F$ expression in driving these seasonal responses. The function of the dmpARC itself is not clear; as one recent study found that SD-induced weight loss could occur in hamsters with lesions of this structure (Teubner et al. 2015). However, other lines of evidence suggest that increased VGF expression in the dmpARC could contribute to the SD-catabolic state, for example, at least one of the peptide products (TLQP-21) has been shown to reduce appetite when infused centrally into the hamster (Jethwa et al. 2007).

Repression of VGF promoter activity was nullified via the removal of the potential TRE from the promoter construct. TREs have previously been shown to be responsible for the dose-dependent $\mathrm{T}_{3}$ repression of $\mathrm{Mc} 4 \mathrm{r}$ promoter activity (Decherf et al. 2010). Furthermore, TREs have been shown to function in combination with RAR/RXR (De Luca 1991). Heterodimerization of the TR with RXR favors the dissociation of suppressors and the recruitment of activators of transcription (Cheung et al. 2009). Therefore, we hypothesize that the inability of TR to heterodimerize with RXR results in the repression of VGF in the hypothalamus of SD Siberian hamsters.

Additionally, we demonstrate that $1,25 \mathrm{D}_{3}$, the active metabolite of vitamin D, significantly increases VGF endogenous mRNA expression and promoter activity in both undifferentiated and differentiated SH-SY5Y cells. However, further studies are required to determine the effects of $1,25 \mathrm{D}_{3}$ in vivo. The seasonal regulation of the harderian gland of Siberian hamsters has been shown to be regulated by vitamin D (Perez-Delgado et al. 1993, Stumpf et al. 1993), while we have shown that plasma vitamin $D_{3}$ levels in adult hamsters are significantly higher in SD than in LD (SI Anderson, M Smith \& FJP Ebling, unpublished observations). Interestingly, $1,25 \mathrm{D}_{3}$ has been shown to have neuroprotective qualities in vitro (Brewer et al. 2001, Oermann et al. 2004, Wang et al. 2004), while treatment of the SH-SY5Y cell line with $1,25 \mathrm{D}_{3}$ inhibits proliferation (Celli et al. 1999), similar to the effects of RA. However, long-term incubation with $1,25 \mathrm{D}_{3}$ only resulted in a slight trend towards differentiation (Celli et al. 1999). More recently, Agholme et al. (2010) demonstrated that pretreatment with RA followed by extracellular matrix gel adhesion, in combination with brain-derived neurotrophic factor (BDNF), neuregulin $\mathrm{B} 1$, NGF and $1,25 \mathrm{D}_{3}$, resulted in differentiated $\mathrm{SH}-\mathrm{SY} 5 \mathrm{Y}$ cells with unambiguous resemblance to adult neurons. The results presented here support the idea of differentiation-induced expression of the VGF gene and, therefore a possible role in

Published by Bioscientifica Ltd. 


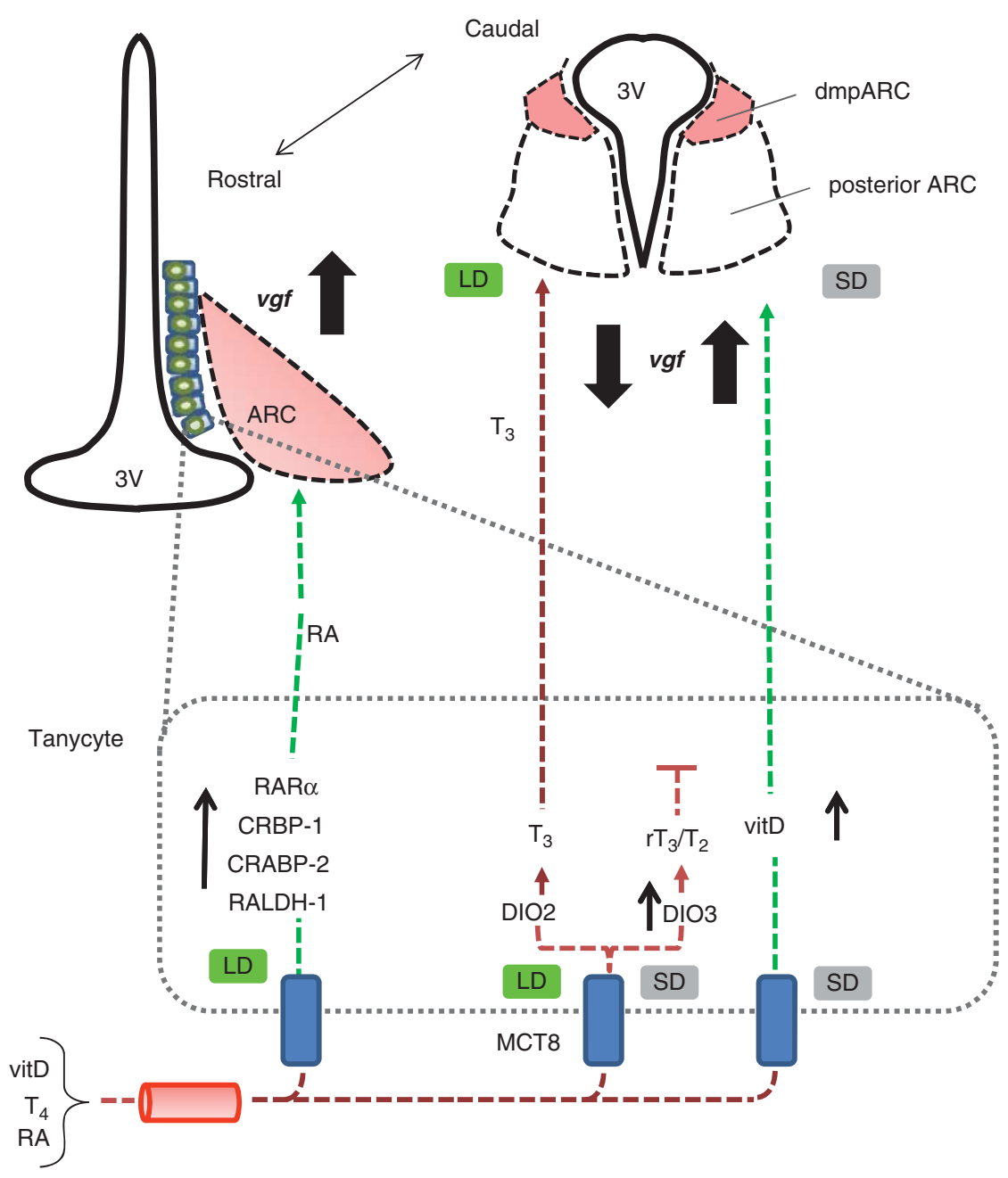

Figure 5

Schematic summary of the proposed photoneuroendocrine control of VGF expression. Thyroxine $\left(T_{4}\right)$ is taken up from the circulation into tanycytes via MCT8 transporters, and in LD is converted by DIO2 to $\mathrm{T}_{3}$ (Ebling 2014). Furthermore, in LD, components of the retinoic acid-signaling pathway CRBP-1, CRABP-2, RAR, and RXR - are all upregulated in the Siberian hamster (Ross et al. 2005, Barrett et al. 2006), while RALDH-1 is increased in the photoperiodic rat (Shearer et al. 2010). We demonstrate that VGF expression and promoter activity in SH-SY5Y cells is increased in response to treatment

neurogenesis. This agrees with previous studies from Esposito et al. (2008), who suggests that receptor tyrosine kinase (RET) activation is a critical step in differentiation. Indeed, Korecka et al. (2013) have shown that RA induces RET expression in SH-SY5Y cells, while Cerchia et al. (2006) have suggested that inhibition of RET in SK-N-BE cells increases VGF expression. Moreover, a recent study in mice has demonstrated that the VGF-derived peptide, TLQP-62, directly increased the generation of neural progenitor cells in the hippocampus and potentiated BDNF-TrkB signalling (Thakker-Varia et al. 2014), thus with RA and vitamin $D$ and reduced in response to treatment with $T_{3}$. Furthermore, VGF mRNA expression is reduced in response to intrahypothalamic $\mathrm{T}_{3}$ administration in the SD-exposed Siberian hamster. In SD, expression of $\mathrm{DIO}_{3}$ is upregulated, and thus, inactive metabolites of $\mathrm{T}_{4}$ such as $\mathrm{rT}_{3}$ and $\mathrm{T}_{2}$ are produced alongside reductions in components of the retinoic acid-signaling pathway, while vitamin $D$ plasma levels are increased. This may account for the increase in VGF expression in the dmpARC whilst reducing VGF expression in the ARC. Adapted from Ebling (2014).

the concept that enhanced VGF expression promotes neurogenesis and plasticity is rapidly gaining ground.

In conclusion, this study demonstrates that $\mathrm{T}_{3}$ and $1,25 \mathrm{D}_{3}$, as well as NGF and RA, regulate endogenous VGF expression and promoter activity in vitro, while $\mathrm{T}_{3}$ regulates VGF mRNA expression in vivo, providing a possible mechanism for the seasonal regulation of appetite in the Siberian hamster (Fig. 5), as well as suggesting a possible role for $V G F$ in neurogenesis. Furthermore, it substantiates the central role of $\mathrm{T}_{3}$ and $1,25 \mathrm{D}_{3}$ in neuroendocrine and metabolic signaling. 


\section{Declaration of interest}

The authors declare that there is no conflict of interest that could be perceived as prejudicing the impartiality of the research reported.

\section{Funding}

The work was supported by a University of Nottingham Knowledge Transfer Award and a BBSRC PhD studentship and Strategic Skills Award; and by project grants from the Scottish Government Rural and Environment Science and Analytical Services Division and the BBSRC (BBS/B/10765).

\section{Author contribution statement}

J E L: conducted the studies, analyzed the data and drafted the manuscript; J M B: guidance during experiments, analysis of data and reviewed draft manuscript; $\mathrm{P} \mathrm{H}$ : guidance during experiments; $\mathrm{D} \mathrm{W}$ and $\mathrm{P} \mathrm{B}$ : in situ hybridisation studies and analysis; F J P E: expertise with regards to seasonal models, in vivo study, analysis of data and reviewed draft manuscript; $\mathrm{P} \mathrm{H} \mathrm{J:}$ principal investigator, analysis of results, reviewed draft manuscript and final sign off of manuscript.

\section{References}

Agholme L, Lindstrom T, Kagedal K, Marcusson J \& Hallbeck M 2010 An in vitro model for neuroscience: differentiation of SH-SY5Y cells into cells with morphological and biochemical characteristics of mature neurons. Journal of Alzheimer's Disease 20 1069-1082. (doi:10.3233/ JAD-2010-091363)

Anzano MA, Lamb AJ \& Olson JA 1979 Growth, appetite, sequence of pathological signs and survival following the induction of rapid, synchronous vitamin A deficiency in the rat. Journal of Nutrition 109 1419-1431.

Barrett P, Ross AW, Balik A, Littlewood PA, Mercer JG, Moar KM, Sallmen T, Kaslin J, Panula P, Schuhler S et al. 2005 Photoperiodic regulation of histamine $\mathrm{H} 3$ receptor and VGF messenger ribonucleic acid in the arcuate nucleus of the Siberian hamster. Endocrinology 146 1930-1939. (doi:10.1210/en.2004-1452)

Barrett P, Ivanova E, Graham ES, Ross AW, Wilson D, Ple H, Mercer JG, Ebling FJ, Schuhler S, Dupre SM et al. 2006 Photoperiodic regulation of cellular retinol binding protein, CRBP1 [corrected] and nestin in tanycytes of the third ventricle ependymal layer of the Siberian hamster. Journal of Endocrinology 191 687-698. (doi:10.1677/ joe.1.06929)

Barrett P, Ebling FJ, Schuhler S, Wilson D, Ross AW, Warner A, Jethwa P, Boelen A, Visser TJ, Ozanne DM et al. 2007 Hypothalamic thyroid hormone catabolism acts as a gatekeeper for the seasonal control of body weight and reproduction. Endocrinology 148 3608-3617. (doi:10.1210/en.2007-0316)

Bartness TJ, Hamilton JM, Wade GN \& Goldman BD 1989 Regional differences in fat pad responses to short days in Siberian hamsters. American Journal of Physiology 257 R1533-R1540.

van Bennekum AM, Wei S, Gamble MV, Vogel S, Piantedosi R, Gottesman M, Episkopou V \& Blaner WS 2001 Biochemical basis for depressed serum retinol levels in transthyretin-deficient mice. Journal of Biological Chemistry 276 1107-1113. (doi:10.1074/jbc.M008091200)

Bolborea M \& Dale N 2013 Hypothalamic tanycytes: potential roles in the control of feeding and energy balance. Trends in Neurosciences $\mathbf{3 6}$ 91-100. (doi:10.1016/j.tins.2012.12.008)

Brewer LD, Thibault V, Chen KC, Langub MC, Landfield PW \& Porter NM 2001 Vitamin D hormone confers neuroprotection in parallel with downregulation of L-type calcium channel expression in hippocampal neurons. Journal of Neuroscience 21 98-108.
Brown DM, Parr T \& Brameld JM 2012 Myosin heavy chain mRNA isoforms are expressed in two distinct cohorts during $\mathrm{C} 2 \mathrm{C} 12$ myogenesis. Journal of Muscle Research and Cell Motility 32 383-390. (doi:10.1007/ s10974-011-9267-4)

Canu N, Possenti R, Rinaldi AM, Trani E \& Levi A 1997 Molecular cloning and characterization of the human VGF promoter region. Journal of Neurochemistry 68 1390-1399. (doi:10.1046/j.1471-4159.1997. 68041390.x)

Celli A, Treves C \& Stio M 1999 Vitamin D receptor in SH-SY5Y human neuroblastoma cells and effect of 1,25-dihydroxyvitamin $\mathrm{D}_{3}$ on cellular proliferation. Neurochemistry International 34 117-124. (doi:10.1016/ S0197-0186(98)00075-8)

Cerchia L, D'Alessio A, Amabile G, Duconge F, Pestourie C, Tavitian B, Libri D \& de Franciscis V 2006 An autocrine loop involving ret and glial cell-derived neurotrophic factor mediates retinoic acid-induced neuroblastoma cell differentiation. Molecular Cancer Research 4 481-488. (doi:10.1158/1541-7786.MCR-06-0050)

Cheung YT, Lau WK, Yu MS, Lai CS, Yeung SC, So KF \& Chang RC 2009 Effects of all-trans-retinoic acid on human SH-SY5Y neuroblastoma as in vitro model in neurotoxicity research. Neurotoxicology 30 127-135. (doi:10.1016/j.neuro.2008.11.001)

Chu CT, Plowey ED, Dagda RK, Hickey RW, Cherra SJ III \& Clark RS 2009 Autophagy in neurite injury and neurodegeneration: in vitro and in vivo models. Methods in Enzymology 453 217-249. (doi:10.1016/S00766879(08)04011-1)

Decherf S, Seugnet I, Kouidhi S, Lopez-Juarez A, Clerget-Froidevaux MS \& Demeneix BA 2010 Thyroid hormone exerts negative feedback on hypothalamic type 4 melanocortin receptor expression. PNAS 107 4471-4476. (doi:10.1073/pnas.0905190107)

De Luca LM 1991 Retinoids and their receptors in differentiation, embryogenesis, and neoplasia. FASEB Journal 5 2924-2933.

Dwane S, Durack E \& Kiely PA 2013 Optimising parameters for the differentiation of SH-SY5Y cells to study cell adhesion and cell migration. BMC Research Notes 6 366. (doi:10.1186/1756-05006-366)

Ebling FJ 1994 Photoperiodic differences during development in the dwarf hamsters Phodopus-sungorus and Phodopus-campbelli. General and Comparative Endocrinology 95 475-482. (doi:10.1006/gcen.1994.1147)

Ebling FJ 2014 On the value of seasonal mammals for identifying mechanisms underlying the control of food intake and body weight. Hormones and Behavior 66 56-65. (doi:10.1016/j.yhbeh.2014.03.009)

Ebling FJ 2015 Hypothalamic control of seasonal changes in food intake and body weight. Frontiers in Neuroendocrinology 37 97-107. (doi:10.1016/j.yfrne.2014.10.003)

Episkopou V, Maeda S, Nishiguchi S, Shimada K, Gaitanaris GA, Gottesman ME \& Robertson EJ 1993 Disruption of the transthyretin gene results in mice with depressed levels of plasma retinol and thyroid hormone. PNAS 90 2375-2379. (doi:10.1073/pnas.90.6.2375)

Esposito CL, D’Alessio A, de Franciscis V \& Cerchia L 2008 A cross-talk between TrkB and Ret tyrosine kinases receptors mediates neuroblastoma cells differentiation. PLOS ONE 3 e1643. (doi:10.1371/journal. pone.0001643)

Helfer G, Ross AW, Russell L, Thomson LM, Shearer KD, Goodman TH, McCaffery PJ \& Morgan PJ 2012 Photoperiod regulates vitamin A and Wnt/ $\beta$-catenin signaling in F344 rats. Endocrinology 153 815-824. (doi:10.1210/en.2011-1792)

Herwig A, Wilson D, Logie TJ, Boelen A, Morgan PJ, Mercer JG \& Barrett P 2009 Photoperiod and acute energy deficits interact on components of the thyroid hormone system in hypothalamic tanycytes of the Siberian hamster. American Journal of Physiology. Regulatory, Integrative and Comparative Physiology 296 R1307-R1315. (doi:10.1152/ajpregu. 90755.2008)

Holick MF 1995 Environmental factors that influence the cutaneous production of vitamin D. American Journal of Clinical Nutrition 61 638S-645S

Published by Bioscientifica Ltd. 
Hyung SJ, Deroo S \& Robinson CV 2010 Retinol and retinol-binding protein stabilize transthyretin via formation of retinol transport complex. ACS Chemical Biology 5 1137-1146. (doi:10.1021/cb100144v)

Jethwa PH, Warner A, Nilaweera KN, Brameld JM, Keyte JW, Carter WG, Bolton N, Bruggraber M, Morgan PJ, Barrett P et al. 2007 VGF-derived peptide, TLQP-21, regulates food intake and body weight in Siberian hamsters. Endocrinology 148 4044-4055. (doi:10.1210/en.2007-0038)

Klingenspor M, Dickopp A, Heldmaier G \& Klaus S 1996 Short photoperiod reduces leptin gene expression in white and brown adipose tissue of Djungarian hamsters. FEBS Letters 399 290-294. (doi:10.1016/ S0014-5793(96)01343-9)

Korecka JA, van Kesteren RE, Blaas E, Spitzer SO, Kamstra JH, Smit AB, Swaab DF, Verhaagen J \& Bossers K 2013 Phenotypic characterization of retinoic acid differentiated SH-SY5Y cells by transcriptional profiling. PLOS ONE 8 e63862. (doi:10.1371/journal.pone.0063862)

Kovalevich J \& Langford D 2013 Considerations for the use of SH-SY5Y neuroblastoma cells in neurobiology. Methods in Molecular Biology 1078 9-21. (doi:10.1007/978-1-62703-640-5 2)

Lahousse SA, Carter JJ, Xu XJ, Wands JR \& de la Monte SM 2006 Differential growth factor regulation of aspartyl-(asparaginyl)- $\beta$-hydroxylase family genes in SH-Sy5y human neuroblastoma cells. BMC Cell Biology 741. (doi:10.1186/1471-2121-7-41)

Levi A, Eldridge JD \& Paterson BM 1985 Molecular cloning of a gene sequence regulated by nerve growth factor. Science 229 393-395. (doi:10.1126/science.3839317)

Levi A, Ferri GL, Watson E, Possenti R \& Salton SR 2004 Processing, distribution, and function of VGF, a neuronal and endocrine peptide precursor. Cellular and Molecular Neurobiology 24 517-533. (doi:10.1023/B:CEMN.0000023627.79947.22)

Lewis JE, Brameld JM, Hill P, Barrett P, Ebling FJ \& Jethwa PH 2015a The use of a viral 2A sequence for the simultaneous over-expression of both the VGF gene and enhanced green fluorescent protein (eGFP) in vitro and in vivo. Journal of Neuroscience Methods 256 22-29. (doi:10.1016/j. jneumeth.2015.08.013)

Lewis JE, Brameld JM \& Jethwa PH $2015 b$ Neuroendocrine role for VGF. Front Endocrinol 6 3. (doi:10.3389/fendo.2015.00003)

Mercer JG, Moar KM, Logie TJ, Findlay PA, Adam CL \& Morgan PJ 2001 Seasonally inappropriate body weight induced by food restriction: effect on hypothalamic gene expression in male Siberian hamsters. Endocrinology 142 4173-4181. (doi:10.1210/endo.142.10.8454)

Murphy M, Jethwa PH, Warner A, Barrett P, Nilaweera KN, Brameld JM \& Ebling FJ 2012 Effects of manipulating hypothalamic triiodothyronine concentrations on seasonal body weight and torpor cycles in Siberian hamsters. Endocrinology 153 101-112. (doi:10.1210/en.2011-1249)

Oermann E, Bidmon HJ, Witte OW \& Zilles K 2004 Effects of $1 \alpha, 25$ dihydroxyvitamin $\mathrm{D}_{3}$ on the expression of HO-1 and GFAP in glial cells of the photothrombotically lesioned cerebral cortex. Journal of Chemical Neuroanatomy 28 225-238. (doi:10.1016/j.jchemneu.2004.07.003)

Ogilvie KM, Saladin R, Nagy TR, Urcan MS, Heyman RA \& Leibowitz MD 2004 Activation of the retinoid $\mathrm{X}$ receptor suppresses appetite in the rat. Endocrinology 145 565-573. (doi:10.1210/en.2003-0907)

Perez-Delgado MM, Bidmon HJ, Bartke A \& Stumpf WE 1993 Vitamin D (soltriol) target cells in the harderian gland of the Siberian hamster (Phodopus sungorus). Acta Anatomica 147 174-177. (doi:10.1159/ 000147500)

Prendergast BJ, Mosinger B Jr, Kolattukudy PE \& Nelson RJ 2002 Hypothalamic gene expression in reproductively photoresponsive and photorefractory Siberian hamsters. PNAS 99 16291-16296. (doi:10.1073/pnas.232490799)
Robins SC, Stewart I, McNay DE, Taylor V, Giachino C, Goetz M, Ninkovic J, Briancon N, Maratos-Flier E, Flier JS et al. $2013 \alpha$-Tanycytes of the adult hypothalamic third ventricle include distinct populations of FGF-responsive neural progenitors. Nature Communications 42049. (doi:10.1038/ncomms3049)

Ross AW, Webster CA, Mercer JG, Moar KM, Ebling FJ, Schuhler S, Barrett P \& Morgan PJ 2004 Photoperiodic regulation of hypothalamic retinoid signaling: association of retinoid $\mathrm{X}$ receptor $\gamma$ with body weight. Endocrinology 145 13-20. (doi:10.1210/en.2003-0838)

Ross AW, Bell LM, Littlewood PA, Mercer JG, Barrett P \& Morgan PJ 2005 Temporal changes in gene expression in the arcuate nucleus precede seasonal responses in adiposity and reproduction. Endocrinology 146 1940-1947. (doi:10.1210/en.2004-1538)

Rossi A, Granata F, Augusti-Tocco G, Canu N, Levi A \& Possenti R 1992 Expression in murine and human neuroblastoma cell lines of VGF, a tissue specific protein. International Journal of Developmental Neuroscience 10 527-534. (doi:10.1016/0736-5748(92)90053-3)

Salton SR, Fischberg DJ \& Dong KW 1991 Structure of the gene encoding VGF, a nervous system-specific mRNA that is rapidly and selectively induced by nerve growth factor in PC12 cells. Molecular and Cellular Biology 11 2335-2349. (doi:10.1128/MCB.11.5.2335)

Shearer KD, Goodman TH, Ross AW, Reilly L, Morgan PJ \& McCaffery PJ 2010 Photoperiodic regulation of retinoic acid signaling in the hypothalamus. Journal of Neurochemistry 112 246-257. (doi:10.1111/ j.1471-4159.2009.06455.x)

Stritzker J, Huppertz S, Zhang Q, Geissinger U, Hartl B, Gentschev I \& Szalay AA 2014 Inducible gene expression in tumors colonized by modified oncolytic vaccinia virus strains. Journal of Virology $\mathbf{8 8}$ 11556-11567. (doi:10.1128/JVI.00681-14)

Stumpf WE, Perez-Delgado MM, Li L, Bidmon HJ \& Tuohimaa P 1993 Vitamin $\mathrm{D}_{3}$ (soltriol) nuclear receptors in abdominal scent gland and skin of Siberian hamster (Phodopus sungorus) localized by autoradiography and immunohistochemistry. Histochemistry 100 115-119. (doi:10.1007/BF00572897)

Teubner BJ, Leitner C, Thomas MA, Ryu V \& Bartness TJ 2015 An intact dorsomedial posterior arcuate nucleus is not necessary for photoperiodic responses in Siberian hamsters. Hormones and Behavior 70 22-29. (doi:10.1016/j.yhbeh.2014.12.011)

Thakker-Varia S, Behnke J, Doobin D, Dalal V, Thakkar K, Khadim F, Wilson E, Palmieri A, Antila H, Rantamaki T et al. 2014 VGF (TLQP-62)induced neurogenesis targets early phase neural progenitor cells in the adult hippocampus and requires glutamate and BDNF signaling. Stem Cell Research 12 762-777. (doi:10.1016/j.scr.2014.03.005)

Wang TT, Nestel FP, Bourdeau V, Nagai Y, Wang Q, Liao J, Tavera-Mendoza L, Lin R, Hanrahan JW, Mader S et al. 2004 Cutting edge: 1,25-dihydroxyvitamin $\mathrm{D}_{3}$ is a direct inducer of antimicrobial peptide gene expression. Journal of Immunology 173 2909-2912. (doi:10.4049/jimmunol.173.5.2909)

Watanabe M, Yasuo S, Watanabe T, Yamamura T, Nakao N, Ebihara S \& Yoshimura T 2004 Photoperiodic regulation of type 2 deiodinase gene in Djungarian hamster: possible homologies between avian and mammalian photoperiodic regulation of reproduction. Endocrinology 145 1546-1549. (doi:10.1210/en.2003-1593)

Webb AR, Kline L \& Holick MF 1988 Influence of season and latitude on the cutaneous synthesis of vitamin $\mathrm{D}_{3}$ : exposure to winter sunlight in Boston and Edmonton will not promote vitamin $\mathrm{D}_{3}$ synthesis in human skin. Journal of Clinical Endocrinology and Metabolism 67 373-378. (doi:10.1210/jcem-67-2-373)

Received in final form 1 December 2015

Accepted 3 December 2015

Accepted Preprint published online 7 December 2015 http://jme.endocrinology-journals.org

DOI: 10.1530/JME-15-0224
(C) 2016 The authors Printed in Great Britain
Published by Bioscientifica Ltd 